\title{
PROVISION OF PUBLIC HOUSING IN JAKARTA
}

\author{
Nina Nurdiani \\ Department of Architecture, Faculty of Engineering, Binus University \\ Jalan K.H. Syahdan No. 9, Palmerah, Jakarta Barat 11480 \\ nnurdiani@binus.edu / nina.nurdiani@yahoo.co.id
}

\begin{abstract}
Public housing is a residential provided by the government for the lower-middle class in city, to be owned. Since 2007, public housing in Jakarta has been built in the form of multi-storey housing (Rusunami). Rusunami is still regarded as one of the best alternatives for the provision of public housing in Jakarta, since the land in the city is very limited and the population is increasing. However, in the development of Rusunami, the displacement of residential units in rusunami is still happening until now. It is necessary to study how the provision of rusunami in Jakarta, whether it meets the needs and target hosts. The study was conducted using a descriptive method which studied provision of rusunami, and other secondary data regarding occupants. The study shows that the increasing number of residential units at rusunami has not covered the needs of residential in Jakarta for the lower-middle class. Occupants in rusunami are generally middle-income families. This condition indicates that the number of residential units and the fulfillment of target criteria at rusunami in Jakarta are still lacking.
\end{abstract}

Keywords: jakarta, multi-storey housing/low cost housing, public housing

\begin{abstract}
ABSTRAK
Perumahan publik merupakan hunian yang disediakan oleh pemerintah bagi masyarakat berpenghasilan menengah ke bawah di perkotaan, untuk dimiliki penghuni. Mulai tahun 2007, pengadaan perumahan publik di Jakarta dibangun dalam bentuk Rumah Susun Sederhana Milik (Rusunami). Rusunami masih dianggap sebagai salah satu alternatif terbaik saat ini untuk penyediaan perumahan publik di Jakarta, mengingat lahan di kota Jakarta yang semakin sangat terbatas luasnya dan jumlah penduduk kota Jakarta yang semakin meningkat. Namun dalam perkembangan rusunami, pengalihan unit hunian rusunami masih terjadi sampai saat ini. Karenanya, perlu dilakukan studi bagaimana penyediaan rusunami di Jakarta, apakah sudah memenuhi kebutuhan dan target sasaran penghuni. Studi dilakukan dengan metode deskriptif yang mempelajari data penyediaan rumah susun, dan data sekunder lainnya mengenai penghuni. Hasil studi menunjukkan bahwa penambahan jumlah unit hunian rusunami masih belum dapat menutup kebutuhan hunian di Jakarta bagi masyarakat berpenghasilan menengah ke bawah. Penghuni umumnya adalah keluarga yang berpenghasilan menengah. Kondisi ini menunjukkan bahwa kebutuhan unit hunian rusunami di Jakarta masih kurang dalam jumlah dan pemenuhan kriteria penghuni sesuai target sasaran.
\end{abstract}

Kata kunci: jakarta, perumahan publik, rumah susun sederhana milik (rusunami) 


\section{PENDAHULUAN}

Jakarta sebagai kota pemerintahan, perekonomian dan jasa terbesar di Indonesia, sampai saat ini masih menjadi tujuan utama para pendatang dari luar daerah Jakarta untuk mencari penghidupan yang lebih baik untuk meningkatkan taraf kesejahteraan mereka. Pada prosesnya, kedatangan kaum pendatang ini menimbulkan masalah sosial tersendiri, khususnya penyediaan perumahan. Masyarakat pendatang yang sebagian besar dari desa dengan tingkat pendidikan yang rendah, membuat mereka menjadi masyarakat berpenghasilan rendah di kota Jakarta dengan budaya tinggal pedesaan, dan memadati pemukiman kampung kota di pusat kota Jakarta khususnya di lahan illegal atau lahan milik pemerintah. Sehingga sampai kini, kota Jakarta masih dipadati oleh kampung kota yang kumuh dan padat penduduknya.

Setiap orang berhak hidup sejahtera dan mendapatkan lingkungan tempat tinggal yang baik dan sehat, termasuk di lingkungan perkotaan. Dalam rangka menyediakan perumahan yang terjangkau bagi masyarakat berpenghasilan rendah di perkotaan, maka pemerintah Indonesia membangun rumah susun sederhana, guna menyediakan lingkungan tempat tinggal yang layak huni, sehat, dan aman.

Untuk mengatur jalannya program rumah susun di Indonesia, maka pada tahun 1985 ditetapkan Undang-Undang tentang Rumah Susun. Undang-undang ini terus disempurnakan agar sesuai dengan tujuan dan kebutuhan di masyarakat yang terus berkembang. Pada tahun 2011 Pemerintah Republik Indonesia menerbitkan Undang-Undang Nomor 20 tahun 2011 tentang Rumah Susun.

Rumah susun adalah bangunan gedung bertingkat yang dibangun dalam suatu lingkungan yang terbagi dalam bagian-bagian yang distrukturkan secara fungsional, baik dalam arah horizontal maupun vertikal dan merupakan satuan-satuan yang masing-masing dapat dimiliki dan digunakan secara terpisah, terutama untuk tempat hunian yang dilengkapi dengan bagian bersama, benda bersama, dan tanah bersama (Bab I, Pasal 1, Undang-Undang Republik Indonesia Nomor 20 tahun 2011 tentang Rumah Susun).

Satuan rumah susun (sarusun/unit rumah susun) memiliki fungsi utama sebagai tempat hunian dan mempunyai sarana penghubung ke jalan umum. Tanah bersama untuk bangunan digunakan atas dasar hak bersama. Rumah susun memiliki bagian bersama yang dimiliki secara tidak terpisah untuk pemakaian bersama, antara lain pondasi, kolom, balok, dinding, lantai, atap, talang air, tangga, lift, selasar, saluran, pipa, jaringan listrik, gas dan telekomunikasi. Rumah susun juga memiliki benda bersama yang bukan merupakan bagian rumah susun untuk pemakaian bersama, antara lain ruang pertemuan, tanaman, bangunan pertamanan, bangunan sarana sosial, tempat ibadah, tempat bermain, tempat parkir terpisah atau menyatu dengan struktur bangunan rumah susun.

Rumah susun sederhana milik termasuk kategori rumah susun umum atau perumahan publik, yaitu rumah susun atau perumahan yang dibangun untuk memenuhi kebutuhan rumah bagi masyarakat berpenghasilan rendah di perkotaan untuk dimiliki oleh penghuni. Masyarakat berpenghasilan rendah (MBR) adalah masyarakat yang mempunyai keterbatasan daya beli, sehingga perlu mendapat dukungan pemerintah untuk memperoleh sarusun umum. Sertifikat hak milik sarusun (SHM sarusun) adalah tanda bukti kepemilikan atas sarusun. Sarusun umum yang memperoleh kemudahan dari pemerintah hanya dapat dimiliki atau disewa oleh masyarakat berpenghasilan rendah.

Sesuai Undang-Undang Republik Indonesia Nomor 20 tahun 2011 tentang rumah susun, penyelenggaraan rumah susun bertujuan untuk meningkatkan efisiensi dan efektifitas pemanfaatan ruang dan tanah di perkotaan, serta menyediakan lebih banyak ruang terbuka hijau di kawasan perkotaan, mengurangi luasan dan mencegah timbulnya perumahan dan permukiman kumuh, 
menjamin terpenuhinya kebutuhan rumah susun yang layak huni dan terjangkau, terutama bagi masyarakat berpenghasilan rendah, dan memberi kepastian hukum kepemilikan sarusun.

Undang-Undang Republik Indonesia Nomor 20 tahun 2011 tentang rumah susun juga menyebutkan bahwa bangunan rusun harus memenuhi persyaratan teknis pembangunan rumah susun, meliputi persyaratan peruntukan lokasi, serta intensitas dan arsitektur bangunan, dan keandalan bangunan yang meliputi persyaratan keselamatan, kesehatan, dan kemudahan. Pengelolaan rumah susun umum dilaksanakan oleh pengelola berbadan hukum atau yang ditunjuk oleh pemerintah. Pengelola berhak menerima sejumlah biaya pengelolaan yang dibebankan kepada pemilik dan penghuni secara proporsional berdasarkan perhitungan kebutuhan biaya operasional, pemeliharaan dan perawatan rumah susun.

Pelaksanaan program rumah susun di Jakarta berupa pembangunan rumah susun sederhana milik yang dibangun dalam rangka meningkatkan harkat, martabat dan kesejahteraan penduduk miskin di Jakarta, terutama penghuni kawasan pemukiman kumuh. Rumah susun sederhana dibangun dengan luas tiap unitnya relatif kecil yaitu tipe 18 untuk dihuni maksimum 4 orang dan tipe 21 untuk dihuni maksimum 5 orang, (Keputusan Gubernur Kepala Daerah Khusus Ibukota Jakarta Nomor 942 Tahun 1991 tentang Peraturan Pelaksanaan Rumah Susun di Daerah Khusus Ibukota Jakarta). Harga jual maksimum tiap unitnya relatif murah. Konsep penjualannya, harga paling rendah berada di lantai teratas dan harga paling tinggi pada lantai terbawah.

Berdasarkan Lampiran II Surat Keputusan Menteri Negara Perumahan Rakyat Nomor 04/KPTS/1995 tanggal 11 April 1995, masyarakat yang menjadi target sasaran penghuni rumah susun sederhana di Jakarta adalah mereka yang memiliki batas maksimum penghasilan keluarga sebesar Rp. 450.000,- (empat ratus lima puluh ribu rupiah) per bulan untuk unit hunian tipe $18 \mathrm{~m}^{2}$, dan mereka yang memiliki batas maksimum penghasilan keluarga sebesar Rp. 750.000,- (tujuh ratus lima puluh ribu rupiah) per bulan untuk unit hunian tipe $21 \mathrm{~m}^{2}$.

Dengan adanya Peraturan Menteri Negara Perumahan Rakyat Nomor: 7/Permen/M/2007 tentang Pengadaan Perumahan dan Permukiman dengan Dukungan Fasilitas Subsidi Perumahan melalui KPR Sarusun Bersubsidi dalam rangka mendorong program percepatan pembangunan rumah susun di kawasan perkotaan yang dimulai tahun 2007, maka kelompok sasaran penghuni rumah susun milik bersubsidi adalah mereka yang berpenghasilan menengah ke bawah atau berpenghasilan rendah dengan besar penghasilan keluarga maksimum Rp. 4.500.000,- (empat juta lima ratus ribu rupiah) per bulan, dan minimum Rp. 1.200.000,- (satu juta dua ratus ribu rupiah) per bulan. Sedangkan mereka yang memiliki penghasilan di bawah Rp. 1.200.000,- (satu juta dua ratus ribu rupiah) per bulan disarankan untuk menyewa rumah susun di perkotaan.

Pada perkembangan pembangunan rumah susun, diduga kepemilikan rumah susun di Jakarta mengalami proses pengalihan penghunian (displacement) baik pada rumah susun yang sudah lama dibangun, maupun yang baru dibangun. Pengalihan penghunian terjadi dari pemilik rumah susun kepada pihak lain yang membutuhkan atau berminat dengan sistem jual beli atau sistem sewa. Sehingga penghuni umumnya bukan lagi kelompok sasaran. Karakteristik dan strata sosial penghuni berubah dari masyarakat berpenghasilan rendah kepada masyarakat berpenghasilan menengah ke atas.

Dalam kegiatan bermukim di suatu lingkungan hunian, Kim, Horner, dan Marans (2005) menyatakan bahwa ada hubungan yang erat antara siklus kehidupan penghuni (life cycle) dan tahapan kehidupan (life stage) penghuni, dengan pilihan lokasi hunian dan lokasi tempat tempat kerja. Masyarakat yang memiliki penghasilan menengah belum mampu memiliki rumah di kota, namun mereka membutuhkan tempat tinggal di perkotaan yang lokasinya dekat dengan tempat bekerja, dekat transportasi umum atau di lokasi hunian yang memiliki tingkat aksesibilitas tinggi. Sedangkan, masyarakat berpenghasilan rendah disediakan perumahan oleh pemerintah dalam bentuk rumah susun di perkotaan yang bisa dimiliki, namun mereka tidak memiliki kemampuan cukup untuk memiliki 
bahkan dengan cara mencicil. Sehingga, terjadilah fenomena pengalihan penghunian di rumah susun, yaitu masyarakat berpenghasilan rendah memindahkan hak kepemilikannya atau hak pakainya kepada masyarakat berpenghasilan menengah ke atas.

Untuk mengendalikan terjadinya fenomena alih huni rumah susun yang dapat saja berlangsung terus menerus, maka perlu adanya studi dengan metode deskriptif mengenai penyediaan rumah susun bagi masyarakat berpenghasilan menengah ke bawah, khususnya di Jakarta, yang hasilnya dapat memberi gambaran atau masukan untuk dapat mengendalikan fenomena ini, sehingga percepatan penyediaan perumahan di Jakarta khususnya bagi masyarakat berpenghasilan menengah ke bawah dapat segera tercapai sesuai target sasaran.

\section{METODE}

Studi penyediaan perumahan publik atau rumah susun di Jakarta dilakukan dengan metode deskriptif untuk mengidentifikasi dan mengetahui bagaimana penyediaan perumahan publik (rumah susun) di Jakarta. Studi dilakukan di rumah susun yang dapat mewakili lima wilayah DKI Jakarta. Studi dilakukan dengan mempelajari data penyediaan rumah susun, dan data sekunder lainnya terkait penyediaan rusunami. Pengumpulan data dilakukan dengan survey data primer dan data sekunder melalui observasi, wawancara dan studi literatur. Hasil dari studi ini diharapkan dapat menjadi masukan bagi pengembangan perumahan di Indonesia, khususnya perumahan bagi masyarakat berpenghasilan rendah yang berada di perkotaan.

\section{HASIL DAN PEMBAHASAN}

Jumlah penduduk DKI Jakarta berdasarkan hasil estimasi Survei Sosial Ekonomi Nasional (Susenas) 2006, bahwa penduduk Jakarta berjumlah 8,96 juta jiwa. Dengan luas wilayah $661,52 \mathrm{~km}^{2}$ berarti kepadatan penduduknya mencapai 13,5 ribu jiwa/km², sehingga menjadikan Jakarta sebagai wilayah yang terpadat penduduknya di Indonesia. Menurut data Biro Pusat Statistik, jumlah penduduk Jakarta tahun 2010 adalah 9,61 juta jiwa. Data tersebut menunjukkan adanya peningkatan jumlah penduduk Jakarta sebesar 0,65 juta jiwa dalam waktu empat tahun.

Menurut hasil telaah Evers (1995), kalangan pekerja di Jakarta sebagian besar berasal dari desa, dan mereka bukanlah kelas pekerja seperti yang ditemukan dalam suatu masyarakat industri. Kaum miskin kota inilah yang bisa dibilang menjadi dominan di Jakarta atau penghuni utama Jakarta. Karena penghasilan mereka relatif rendah, mereka memadati wilayah perkampungan di perkotaan, sehingga ciri utama kampung kota adalah padat dan kumuh.

Jakarta pada kenyataannya adalah sebuah kampung besar. Kondisi dan perilaku masyarakatnya belum sepenuhnya bercirikan masyarakat kota, tetapi lebih mengacu pada semangat dan kebiasaan hidup orang-orang desa yang kebetulan tinggal di kota atau perkotaan. Seperti terlihat pada tabel 1 dan tabel 2 mengamati bagaimana sebaran kaum pendatang beserta prosentasi jumlah penduduk di lima wilayah DKI Jakarta (Wahyu, 2007). 
Tabel 1 Sebaran Penduduk Pendatang di DKI Jakarta

\begin{tabular}{lc}
\hline \multicolumn{1}{c}{ Wilayah } & Prosentasi Sebaran Penduduk Pendatang \\
\hline Jakarta Timur & $41 \%$ \\
Jakarta Pusat & $16 \%$ \\
Jakarta Barat & $5 \%$ \\
Jakarta Utara & $7 \%$ \\
Jakarta Selatan & $30 \%$ \\
Kepulauan Seribu & $1 \%$ \\
\hline
\end{tabular}

Tabel 2 Penduduk DKI Jakarta

\begin{tabular}{lc}
\hline Wilayah & Prosentasi Jumlah Penduduk \\
\hline Jakarta Timur & $31 \%$ \\
Jakarta Pusat & $10 \%$ \\
Jakarta Barat & $23 \%$ \\
Jakarta Utara & $16 \%$ \\
Jakarta Selatan & $20 \%$ \\
Kepulauan Seribu & $0 \%$ \\
\hline
\end{tabular}

Tabel 3 Tingkat Pendidikan Penduduk DKI Jakarta

\begin{tabular}{lc}
\hline Tingkat Pendidikan & Prosentasi Jumlah Penduduk \\
\hline Sekolah Dasar & $20,95 \%$ \\
SLTP & $19,58 \%$ \\
SLTA & $35,23 \%$ \\
Akademi / Universitas & $12,33 \%$ \\
Lainnya (kursus,dll) & $11.91 \%$ \\
\hline
\end{tabular}

Tabel 4 Tingkat Pendapatan Penduduk DKI Jakarta

\begin{tabular}{lc}
\hline \multicolumn{1}{c}{ Tingkat Pendapatan } & Jumlah Pendapatan (Rupiah) \\
\hline Pendapatan Rendah & $<1.700 .000$ \\
Pendapatan Menengah ke bawah & $1.700 .000-3.700 .000$ \\
Pendapatan Menengah ke atas & $3.700 .000-5.700 .000$ \\
Pendapatan Tinggi & $>5.700 .000$ \\
\hline
\end{tabular}

Berdasarkan data dari Biro Pusat Statistik DKI Jakarta tentang tingkat pendidikan masyarakat dan tingkat pendapatan masyarakat di DKI Jakarta, yang digambarkan pada tabel 3 dan tabel 4, dapat dilihat bahwa sebagian besar penduduk Jakarta adalah Masyarakat Berpenghasilan Rendah (MBR).

Tingkat pendidikan yang rendah umumnya cenderung memiliki tingkat pendapatan yang rendah. Masyarakat inilah yang sebenarnya kurang memiliki kemampuan dalam memperoleh rumah atau hunian yang layak bagi kehidupan mereka. Karena penanganan masalah perumahan dan masalah sosial-ekonomi bagi masyarakat berpenghasilan rendah akan dapat memperbaiki kondisi kota secara umum dan mengurangi kesenjangan sosial dalam masyarakat. (BPS DKI Jakarta, 2008)

Pengalihan penghunian (displacement) pada rumah susun adalah perpindahan seseorang dari huniannya semula atau tindakan pengalihan hak kepemilikan perorangan pada rumah susun dari penghuni asal / lama kepada penghuni baru / pengguna. Gambar-gambar dibawah ini memberikan 
gambaran bahwa fenomena pengalihan penghunian di rumah susun terjadi bervariasi pada lokasilokasi rumah susun yang berbeda, dan menunjukkan juga tingkat kehidupan sosial penghuni baru.

Pada gambar 1 terlihat jelas bahwa masyarakat menengah ke atas ikut meramaikan kepemilikan atau penghunian di rumah susun yang seharusnya disediakan bagi masyarakat berpenghasilan rendah. Tanda-tandanya dapat ditunjukkan jelas dengan mulai banyaknya penggunaan Air Conditioning (AC) pada unit-unit hunian, banyaknya mobil yang diparkir menetap di rumah susun, bahkan sampai kendaraan mewah yang menempati fasilitas olah raga dan ruang bersama untuk parkir mobil. Sehingga fasilitas warga rumah susun beralih fungsi.

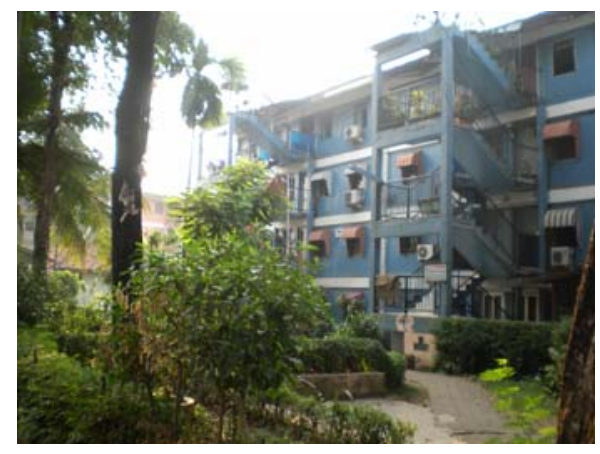

Gambar 1 Suasana di Rumah Susun Klender - Jakarta Timur

Hasil survei rumah susun Pasar Jumat: (1) Mayoritas (40,6\%) penghuni rumah susun Pasar Jumat adalah berpendapatan menengah ke bawah. (Rp.1.700.000 - Rp.3.700.000). (2) sekitar 65,6\% penghuni berstatus penyewa rumah susun sedangkan sisanya $(34,4 \%)$ berstatus Bukan penyewa (pemilik). (3) Penghuni rumah susun Pasar Jumat sebesar 62,5\% tidak memiliki hunian lain.

Hasil studi kepemilikan rumah susun di Kemayoran Jakarta Pusat mengungkapkan bahwa sekitar 60,1\% penghuni asal yang merupakan masyarakat berpenghasilan rendah. Mereka mengalihkan kepemilikannya kepada pendatang. Pendatang merupakan masyarakat berpenghasilan tinggi, karena tingginya biaya tinggal di rusuna.

Hasil survei dan wawancara dengan Ketua Pengelola Rumah Susun Bendungan Hilir I (PPRS Bendungan Hilir I): (1) Mayoritas (38,1\%) penghuni rumah susun saat ini adalah golongan pendapatan menengah atas (Rp.3.700.000 - Rp.5.700.000). (2) Sekitar 42,9\% penghuni berstatus pemilik rumah susun sedangkan sisanya (57,1\%) berstatus bukan pemilik (pengontrak/penyewa). (3) Penghuni rumah susun Bendungan Hilir I sebesar 45,2\% tidak memiliki hunian lain.

Hasil survei pada rumah susun Karet Tengsin: (1) Mayoritas (50\%) penghuni rumah susun saat ini adalah golongan pendapatan menengah bawah (Rp.1.700.000-Rp.3.700.000). (2) Sekitar $63,2 \%$ penghuni berstatus pemilik rumah susun sedangkan sisanya (36,8\%) berstatus bukan pemilik (pengontrak/penyewa). (3) Penghuni rumah susun Karet Tengsin sebesar 71,1\% tidak memiliki hunian lain.

Penentuan lokasi yang tepat bagi rumah susun untuk masyarakat berpenghasilan rendah, sangat menentukan keberhasilan pencapaian sasaran penghunian rumah susun. Karena masyarakat berpenghasilan rendah dengan tingkat kemampuan ekonomi terbatas umumnya cenderung menempati lokasi-lokasi pemukiman kampung kota yang dekat dengan tempat kerja mereka yang umumnya bergerak di sektor informal, melayani dan memberi jasa kepada masyarakat yang tingkat perekonomiannya lebih tinggi. 
Di Indonesia, khususnya Jakarta, kegiatan ekonomi yang terdiri dari sektor formal dan informal akan terus ada dan saling membutuhkan. Lokasi kegiatan sektor formal seperti perkantoran, pemerintahan, perdagangan, jasa komersial dan lain sebagainya berada di pusat-pusat kota di lokasilokasi strategis. Pekerja-pekerja sektor ini adalah masyarakat dengan tingkat pendidikan yang tinggi dan tingkat pendapatan menengah ke atas. Sedangkan kegiatan sektor informal tidak lepas dari keberadaan sektor formal. Lokasi sektor informal selalu mendekati dan melayani kebutuhan masyarakat sektor informal dengan kegiatan seperti pedagang kaki lima, dan lain sebagainya yang umumnya mereka adalah masyarakat dengan tingkat pendidikan rendah dan tingkat pendapatan rendah.

Tentunya kedua pihak membutuhkan hunian yang dekat dengan tempat kerja mereka dan terjangkau dengan kondisi keuangan mereka baik dengan menyewa hunian ataupun membeli hunian di perkotaan. Pemenuhan kebutuhan perumahan perkotaan ini terkait efisiensi waktu dan biaya serta produktivitas dan tenaga. Efisiensi tersebut berguna untuk menjalankan kegiatan perekonomian demi meningkatkan kesejahteraan dan tingkat taraf hidup mereka.

Pada tabel 5, dari hasil survei pendahuluan terhadap lokasi rumah susun, ditemukan bahwa lokasi-lokasi yang mengalami proses pengalihan penghunian pada rumah susun di Jakarta lebih banyak terjadi di pusat kota, di dekat lokasi perkantoran, industri, perdagangan dan jasa, atau lokasi yang memiliki kemudahan dalam mendapatkan aksesibilitas angkutan umum yang murah dan banyak trayeknya. Tentu perlu juga diperhatikan bahwa lokasi-lokasi strategis ini memiliki harga tanah yang sangat mahal. Oleh karena itu, solusi yang baik diperlukan untuk dapat menyediakan rumah susun bagi masyarakat berpenghasilan rendah, menengah, dan tinggi. Adanya proses simbiosis mutualisme antara sektor formal dan informal yang dijelaskan di atas, dapat memberikan pertimbangan pemikiran bagi penyediaan perumahan di perkotaan.

Tabel 5 Presentasi Pengalihan Penghunian pada Rumah Susun dan Lokasi

\begin{tabular}{|c|c|c|c|c|c|c|c|}
\hline Rumah Susun & $\begin{array}{c}\text { Pengalihan } \\
\text { Penghunian } \\
(\%)\end{array}$ & $\begin{array}{c}\text { Tingkat } \\
\text { Pendapatan } \\
\text { Penghuni Baru }\end{array}$ & $\begin{array}{c}\text { Pemilik } \\
\text { Rusun } \\
(\%)\end{array}$ & $\begin{array}{c}\text { Penyewa } \\
\text { Rusun } \\
(\%)\end{array}$ & $\begin{array}{c}\text { Tidak } \\
\text { Memiliki } \\
\text { Hunian Lain }\end{array}$ & Lokasi & Aksesibilitas \\
\hline Pasar Jumat & 59,4 & $\begin{array}{c}\text { Menengah ke } \\
\text { Atas }\end{array}$ & 34,4 & 65,6 & 62,5 & $\begin{array}{l}\text { Jakarta } \\
\text { Selatan }\end{array}$ & Tinggi \\
\hline Kemayoran & 60,1 & Tinggi & - & - & - & $\begin{array}{c}\text { Jakarta } \\
\text { Pusat }\end{array}$ & Tinggi \\
\hline $\begin{array}{l}\text { Bendungan } \\
\text { Hilir I }\end{array}$ & 38,1 & $\begin{array}{c}\text { Menengah ke } \\
\text { Atas }\end{array}$ & 42,9 & 57,1 & 45,2 & $\begin{array}{c}\text { Jakarta } \\
\text { Pusat }\end{array}$ & Sedang \\
\hline Karet Tengsin & 50 & $\begin{array}{c}\text { Menengah ke } \\
\text { Atas }\end{array}$ & 63,2 & 36,8 & 71,1 & $\begin{array}{c}\text { Jakarta } \\
\text { Pusat }\end{array}$ & Tinggi \\
\hline
\end{tabular}

Dari tabel di atas terlihat jelas saat ini telah terjadi pengalihan penghunian pada lokasi survei rata-rata $50 \%$ ke atas. Mayoritas penghuni baru juga rata-rata masyarakat menengah ke atas. Pada lokasi-lokasi strategis dekat pusat kota dengan tingkat aksesibilitas yang tinggi, ada keinginan dari penghuni baru untuk cenderung memiliki rusun. Rata-rata, umumnya mereka tidak memiliki hunian di tempat lain.

Pada pengembangan rumah susun yang selanjutnya, karakteristik masyarakat penghuni rumah susun perlu kiranya dipertimbangkan, yang tentunya memiliki karakteristik yang berbeda. Khususnya karakter penghuni lama dan penghuni baru di rumah susun yang saat ini masih dalam kajian yang lebih lanjut. Diharapkan nanti hasilnya dapat menjadi masukan bagi pengembangan rusun selanjutnya dan mengurangi bahkan dapat menghindari terjadinya pengalihan penghunian rumah susun di perkotaan, yang dapat merugikan masyarakat berpenghasilan rendah dan menghambat pencapaian pemenuhan kebutuhan rumah di perkotaan bagi semua lapisan masyarakat. 
Penyediaan perumahan bagi masyarakat di DKI Jakarta sampai saat ini berdasarkan data dari BPS DKI Jakarta yang bersumber dari Dinas Perumahan DKI Jakarta yang digambarkan pada tabel 6, menunjukkan bahwa penyediaan perumahan di Jakarta lebih banyak difokuskan bagi masyarakat berpenghasilan menengah ke atas. Ini dapat dilihat dari besarnya jumlah pengembangan real estate di wilayah Jakarta Barat dan Jakarta Utara, dan pengembangan apartemen atau kondominium di wilayah Jakarta Selatan dan Jakarta Pusat.

Tabel 6 Banyaknya Rumah Susun, Real Estate, Apartemen/Kondominium di Jakarta

\begin{tabular}{lrrrrrc}
\hline \multirow{2}{*}{ Kotamadya } & Rumah & Susun & Real & Estate & Apartemen / & Kondominium \\
\cline { 2 - 7 } & Lokasi & Unit & Lokasi & Unit & Lokasi & Unit \\
\hline Jakarta Selatan & 3 & 520 & 18 & 14.773 & 55 & 21.343 \\
Jakarta Timur & 13 & 5.021 & 19 & 6.183 & 4 & 3.679 \\
Jakarta Pusat & 10 & 7.278 & - & - & 40 & 28.149 \\
Jakarta Barat & 5 & 3.932 & 31 & 45.217 & 14 & 6.317 \\
Jakarta Utara & 9 & 5.147 & 27 & 38.131 & 12 & 12.006 \\
\hline Jumlah & 40 & 21.898 & 95 & 104.304 & 125 & 71.494 \\
\hline
\end{tabular}

Sedangkan penyediaan rumah susun yang direncanakan untuk masyarakat berpenghasilan rendah jumlahnya belum sesuai bila dibandingkan dengan kebutuhan perumahan bagi mereka sebagai masyarakat pendatang yang dominan menjadi sebagian besar penduduk DKI Jakarta. Pengembangan rumah susun khususnya bagi masyarakat berpenghasilan menengah juga belum terprogram dengan jelas menempati yang mana. Mereka mampu membeli rumah di real estate, tapi lokasinya jauh dari pusat kota Jakarta. Sehingga masyarakat menengah ini yang penghasilannya lumayan besar namun tidak mampu untuk membeli atau menyewa apartemen dan kondominium, mengambil alih sasaran penghunian bagi masyarakat berpenghasilan rendah melalui proses jual beli rumah susun dari penghuni lama kepada penghuni baru.

Lokasi rumah susun saat ini masih terbatas jumlahnya, meskipun jumlah rusun sudah mengikuti pola sebaran penduduk pendatang di lima wilayah DKI Jakarta. Ketidakmampuan masyarakat berpenghasilan rendah membayar sewa, mencicil biaya sewa-beli, ataupun menyediakan dana untuk operasional dan pemeliharaan di rumah susun menyebabkan penghuni lama mengalihkan hak penghuniannya. Namun pengalihan penghunian tidak terjadi di semua lokasi rusun. Penghuni baru cenderung memilih dalam menentukan rumah susun yang akan mereka beli atau sewa.

Strategi penerapan kebijaksanaan pengadaan rumah susun bagi masyarakat berpenghasilan rendah yang dapat mengurangi terjadinya peralihan penghunian pada rumah susun adalah dengan melakukan usaha-usaha sebagai berikut: (1) Melakukan kontrol yang ketat terhadap pemindahtanganan hak penghunian pada rumah susun bagi masyarakat berpenghasilan rendah. (2) Memberikan subsidi pembangunan dan pemeliharaan pada pembangunan rumah susun bagi masyarakat berpenghasilan rendah. (3) Perlu adanya strategi sistem penghunian pada rumah susun untuk masyarakat kaum pendatang berpenghasilan rendah di perkotaan, yang tidak menetap di Jakarta sepanjang hidupnya. (4) Membangun rumah susun bagi golongan masyarakat ekonomi menengah di pusat kota bekerja sama dengan swasta, sehingga menghindari terjadinya pengalihan penghunian rumah susun bagi masyarakat berpenghasilan rendah. (5) Membuat kebijaksanaan yang mengatur pengalihan hak kepemilikan rumah susun dalam jangka waktu tertentu. (6) Melakukan seleksi penghunian yang ketat pada awal penghunian rumah susun. (7) Melakukan penyuluhan dan sosialisasi cara berhuni di rumah susun kepada penghuni. (8) Mencari strategi pengelolaan rumah susun sehingga biayanya dapat terjangkau penghuni yang pendapatannya rendah. Pembangunan penyediaan perumahan oleh pemerintah harus tetap berpihak bagi masyarakat berpenghasilan rendah. Karena merekalah yang perlu mendapat bantuan baik dari masyarakat maupun pemerintah. 


\section{SIMPULAN}

Fenomena pengalihan penghunian pada rumah susun di Jakarta terjadi cukup besar persentasinya (rata-rata lebih dari 50\%), terutama pada rumah susun yang terletak di lokasi-lokasi strategis dekat perkantoran, perdagangan, dan jasa komersial. Fenomena pengalihan penghunian ini harus dikendalikan, karena dapat menghambat pencapaian tujuan pemerintah untuk menyediakan perumahan bagi masyarakat berpenghasilan rendah di perkotaan. Perlu adanya strategi/kebijaksanaan pengadaan rumah susun bagi masyarakat berpenghasilan rendah yang dapat mengurangi terjadinya peralihan penghunian pada rumah susun.

Pembangunan penyediaan perumahan oleh pemerintah harus tetap berpihak bagi masyarakat berpenghasilan rendah. Keberhasilan percepatan pembangunan perumahan, khususnya rumah susun di perkotaan perlu memperhatikan banyak faktor, baik ekonomi, sosial-budaya, kebijakan, proses berhuni masyarakat di rumah susun, lokasi rusun, tempat bekerja mereka, dan aksesibilitas. Tentunya penyuluhan dan sosialisasi tinggal di rumah susun masih perlu digalakkan demi tercapainya pengertian dan pemahaman dari masyarakat untuk harus dapat menyesuaikan tinggal di keterbatasan ruang di lingkungan perkotaan untuk menciptakan kehidupan dan lingkungan yang lebih baik.

Hasil studi juga menunjukkan bahwa penambahan jumlah unit hunian rusunami masih belum dapat menutup kebutuhan hunian di Jakarta bagi masyarakat berpenghasilan menengah ke bawah. Penghuni rumah susun umumnya adalah keluarga yang berpenghasilan menengah. Kondisi ini menunjukkan bahwa kebutuhan unit hunian rusunami di Jakarta masih kurang dan belum memenuhi kriteria penghuni sesuai target sasaran.

\section{DAFTAR PUSTAKA}

Biro Pusat Statistik (2012), Jakarta Dalam Angka 2012, BPS DKI Jakarta, Jakarta.

Biro Pusat Statistik (2008), Jakarta Dalam Angka 2007, BPS DKI Jakarta, Jakarta.

Evers, H.-D. (1995), “Produksi Subsistensi dan 'Massa Apung' Jakarta”. Sosiologi Perkotaan: Urbanisasi dan Sengketa Tanah di Indonesia dan Malaysia, Cetakan Keempat, Jakarta: PT. Pustaka LP3ES Indonesia.

Keputusan Gubernur Kepala Daerah Khusus Ibukota Jakarta Nomor 942 Tahun 1991 tentang Peraturan Pelaksanaan Rumah Susun di Daerah Khusus Ibukota Jakarta.

Kim, T.K., Horner M.W., \& Marans, R.W. (2005), Life Cycle and Environmental Factors in Selecting Residential and Job Locations. Housing Studies, 20(3), 457 - 473.

Surat Keputusan Menteri Negara Perumahan Rakyat. (1995). Lampiran II Surat Keputusan Menteri Negara Perumahan Rakyat Nomor 04/KPTS/1995 tanggal 11 April 1995. Kementerian Negara Perumahan Rakyat. Jakarta.

Peraturan Menteri Negara Perumahan Rakyat. (2007). Peraturan Menteri Negara Perumahan Rakya Nomor: 7/Permen/M/2007 tentang Pengadaan Perumahan dan Permukiman dengan Dukungan Fasilitas Subsidi Perumahan melalui KPR Sarusun Bersubsidi. Kementerian Negara Perumahan Rakyat. Jakarta. 
Republik Indonesia. (1986). Undang-Undang Republik Indonesia Nomor 16 Tahun 1985 tentang Rumah Susun. Sekretariat Negara. Jakarta.

Republik Indonesia. (2011). Undang-Undang Republik Indonesia Nomor 20 tahun 2011 tentang Rumah Susun. Lembaran Negara Republik Indonesia Tahun 2011 Nomor 108. Sekretariat Negara. Jakarta.

Wahyu, Y. (2007), “Potret Urbanisasi Jakarta”, Kompas, 17 November 2007, Jakarta: Gramedia Press. 